\title{
MAREK REWIZORSKI
}

Koszalin

\section{Unia gospodarczo-walutowa: geneza, ewolucja, perspektywy rozwoju}

\section{Teoretyczne aspekty integracji gospodarczej i walutowej w Unii Europejskiej}

Integracja (od łacińskiego: ,integratio” - uzupełnienie oraz ,integer” - całkowity) oznacza tworzenie całości z odrębnych części, natomiast integrować (od łac. ,integrare" - dopełniać) znaczy łączyć w jedną całość, składać z części, jednoczyć ${ }^{1}$. Ogólnie rzecz ujmując integracja gospodarcza może zatem oznaczać dokonujący się w sferze gospodarki proces łączenia w jedną całość pewnych części, odrębnych dotąd elementów. Może się to odbywać zarówno w skali narodowej, tj. w ramach jednego kraju jak również w skali międzynarodowej, tzn. obejmować dwa lub więcej państw oraz ich gospodarki narodowe bądź części tychże gospodarek ${ }^{2}$. Formą międzynarodowej integracji gospodarczej jest integracja regionalna, która następuje na danym obszarze geograficznym (regionie).

Według klasycznej w nauce polskiej definicji, sformułowanej przez Zbigniewa Kameckiego, istotę międzynarodowej (regionalnej) integracji gospodarczej stanowi wytworzenie się, w oparciu o wykształconą, jednolitą strukturę ekonomiczną, pewnego organizmu gospodarczego obejmującego grupę państw, który - ze względu na wysoki stopień powiązań ekonomicznych i osiagniętą w wyniku tego wewnętrzną spoistość ekonomiczną - wyodrębnia się w widoczny sposób z całokształtu gospodarki światowej ${ }^{3}$. Biorąc za podstawę wyżej wskazaną definicję, część autorów ukazuje międzynarodową integrację gospodarczą jako proces charakteryzujący się wysoką dynamiką, prowadzący do powstania globalnej sieci powiązań produkcyjnych, technologicznych, finansowych $\mathrm{i}$ handlowych między gospodarkami narodowymi i ich częściami na świe$\mathrm{cie}^{4}$. Polega on na ,występowaniu szeregu przeobrażeń i dostosowań w strukturze ekonomicznej integrujących się krajów, zachodzących wewnątrz każdego z nich, jak i między nimi i kształtującego jednolitą, tzn. wewnętrznie komplementarną, spójną, a zatem przeobrażoną jakościowo, nową strukturę ekonomiczną całego obszaru",5.

Integracja gospodarcza (w tym zarówno międzynarodowa, jak również regionalna) bywa też definiowana jako proces i jako istniejący stan. Według Béli A. Balassy inte-

1 Por. J. Okarmus, M. Tytuła, Stownik wyrazów obcych, Bielsko-Biała 2011, s. 101.

2 A. Makać, Międzynarodowa integracja gospodarcza-podstawowe problemy teoretyczne, w: Procesy integracyjne we współczesnej gospodarce światowej, red. E. Oziewicz, Warszawa 2001, s. 9.

3 Z. Kamecki, Pojęcie i typy integracji gospodarczej, „Ekonomista” 1967, nr 1, s. 93-94.

4 Globalizacja. Mechanizmy i Wyzwania, red. B. Liberska, Warszawa 2002, s. 19.

5 A. B. Kisiel-Łowczyc, Współczesna gospodarka światowa, Gdańsk 1999, s. 193-194; Z. Kamecki, op. cit. 
gracja jako proces to ciągłe pogłębianie więzi (instytucjonalnych i realnych) między państwami. W jej ramach stosowane są środki zapobiegania dyskryminacji podmiotów gospodarczych ze względu na ich przynależność do różnych państw. Integracja traktowana zaś jako stan oznacza brak występowania między gospodarkami narodowymi różnych przejawów dyskryminacji ${ }^{6}$. Podobny pogląd wyraził Jan Tinbergen, który ponadto zauważył, że można wyróżnić integrację pozytywną i negatywną. Autor ten pod pojęciem ,integracja negatywna” rozumie wszystkie jej aspekty, które obejmują zniesienie dyskryminacji na drodze do liberalizacji. Polega ona na usuwaniu przeszkód w swobodnej wymianie dóbr, usług i czynników produkcji. Wyższym etapem integracji jest „integracja pozytywna” wyrażająca się w modyfikacji istniejących instrumentów i instytucji narodowych oraz tworzeniu instytucji ponadnarodowych, dla efektywniejszego działania rynku i osiagnięcia szerszych celów politycznych. W dużym uproszczeniu integracja pozytywna w ujęciu J. Tinbergena polega na współpracy rządów przy korygowaniu zakłóceń tworzonych przez rynki ${ }^{7}$.

W literaturze pojawiają się nie tylko rozbieżne poglądy co do znaczenia terminu „międzynarodowa (lub regionalna) integracja gospodarcza”, ale też co do metody jej dokonywania. Dominują tu zwłaszcza koncepcje: funkcjonalna (liberalna) i instytucjonalna. Za głównego przedstawiciela pierwszej z nich jest uważany B. Balassa.

Zgodnie z metodą funkcjonalną integracji - działania i funkcje państwa bądź ugrupowania integracyjnego powinny się ograniczać wyłącznie do likwidacji barier w obrotach między grupą zainteresowanych państw. Zapewnienie między nimi swobodnego przepływu towarów oraz czynników produkcji zapewnia niezakłócone działanie mechanizmu wolnego rynku, który w tych warunkach wywołuje proces integracji gospodarczej ${ }^{8}$.

Przy zastosowaniu metody instytucjonalnej, której najbardziej znanym przedstawicielem jest J. Tinbergen, do zainicjowania i podtrzymywania postępów międzynarodowej integracji gospodarczej konieczna jest koordynacja, a następnie unifikacja polityki ekonomicznej prowadzonej przez poszczególne grupy państw. W praktyce może to oznaczać ustanowienie określonych instytucji integracyjnych wyposażonych w kompetencje umożliwiające skuteczną koordynację, unifikację i centralizację polityki ekonomicznej grupy integrujących się państw'

$\mathrm{Z}$ integracją gospodarczą silnie powiązana jest integracja walutowa. Stanowi ona element procesu ogólnej integracji gospodarczej i zmierza do zapewnienia wymienialności walut po nieodwracalnie stałych, sztywnych kursach, a w ostatecznym rozrachunku do zastapienia walut narodowych jedną wspólną walutą ${ }^{10}$. Realizacja tego celu wymaga zapewnienia liberalizacji przepływów kapitału między zainteresowanymi państwami, a zatem zniesienia wszelkich przeszkód w swobodzie cyrkulacji kapitału, stopniowej koordynacji polityki pieniężnej i ogólnogospodarczej państw członkowskich. Można przyjąć, że zakończenie procesu integracji walutowej następuje wraz

${ }^{6}$ B. Balassa, The Theory of Economic Integration, London 1962, s. 1 i n.

7 A. Zielińska-Głębocka, Dynamika Unii Europejskiej w świetle teorii integracji, „Studia Europejskie" 1999 , nr 3, s. 23.

8 A. Makać, Międzynarodowa integracja..., s. 29.

9 Ibidem.

10 P. Kalka, Rola RFN w rozwoju integracji ekonomicznej we Wspólnotach Europejskich, Poznań 2005, s. 111. 
z podjęciem przez instytucję ponadnarodową wspólnej polityki pieniężnej. Innymi słowy wtedy mamy do czynienia z realizacją unii walutowej. Wspólna polityka pieniężna obejmuje:

- emisję wspólnego pieniądza,

- zarządzanie połączonymi dewizami państw członkowskich, oraz

- wspólną politykę walutową ${ }^{11}$.

Jak podkreśla Piotr Kalka, potrzeba rozwijania integracji walutowej w ugrupowaniu integracyjnym, takim jak Unia Europejska wynika z rosnącej współzależności gospodarczej pomiędzy państwami członkowskimi, a także pogłębiania się handlu wewnątrzunijnego. Państwa dążą do zapewnienia sobie stabilnych kursów walutowych, a przez to do wyeliminowania niepewności co do cen i kosztów, oraz ewentualnych trudności w bilansie handlowym i płatniczym mogących negatywnie wpływać na ich sytuację gospodarczą. Załamanie koniunktury mogłoby doprowadzić do zwiększenia zainteresowania stosowaniem środków zagranicznej polityki ekonomicznej o charakterze wyraźnie protekcjonistycznym, utrudniającym czerpanie korzyści z funkcjonowania wspólnego rynku ${ }^{12}$.

Biorąc za podstawę perspektywę integracyjną można zauważyć, że unia gospodarcza i walutowa, która została utworzona w trzech etapach pomiędzy 1990 a 2002 r., jest „organizmem gospodarczym”, obejmującym grupę państw, charakteryzującym się wysokim stopniem powiązań ekonomicznych i znaczną wewnętrzną spoistością ekonomiczną (integracja gospodarcza), na którego obszarze prowadzona jest wspólna polityka pieniężna nadzorowana przez instytucję ponadnarodową (integracja walutowa).

Podstawę koncepcyjną UGiW stanowi neoliberalizm w ujęciu B. Balassy. Ugrupowania integracyjne zostały sprowadzone do roli czynników liberalizujących międzynarodowe przepływy czynników produkcji, towarów i usług między państwami członkowskimi. B. Balassa, w swojej teorii wskazał na istnienie sekwencji etapów integracji, w której każdy kolejny oznaczał coraz dalej posuniętą liberalizację. Tę ostatnią rozumiał jako likwidację barier w obrocie międzynarodowym towarami, usługami, pracą i kapitałem w celu stworzenia warunków niezakłóconego funkcjonowania mechanizmu wolnego rynku. Do etapów integracji i jednocześnie form międzynarodowych ugrupowań integracyjnych zaliczył: strefę wolnego handlu, unię celną, wspólny rynek, unię gospodarczą (ekonomiczno-walutowa), pełną integrację (unię polityczną).

Zastosowanie koncepcji integracji B. Balassy, pozwala rozumieć UGiW na dwa sposoby. Pierwszy z nich wskazuje na postrzeganie UGiW mianem formy międzynarodowego (regionalnego) ugrupowania integracyjnego, którym jest Unia Europejska. $\mathrm{Na}$ rysunku 1 przedstawiono formy międzynarodowych ugrupowań integracyjnych.

Drugim sposobem określania istoty unii gospodarczej i walutowej jest ujmowanie jej jako wyniku sekwencji etapów integracji, w której każdy kolejny oznaczał coraz dalej posuniętą liberalizację.

Konkludując, UGiW można definiować jako proces oraz jako postulowany stan rzeczy, czyli cel, który poszczególne państwa członkowskie zamierzają zrealizować.

11 Por. L. Oręziak, Integracja walutowa, w: Unia Europejska. Podręcznik akademicki, red. L. Ciamaga i inni, Warszawa 1997, s. 231.

12 P. Kalka, Rola RFN..., s. 112. 


\begin{tabular}{|l|l|l|l|l|l|}
\cline { 2 - 6 } \multicolumn{1}{c|}{} & $\begin{array}{c}\text { Likwidacja } \\
\text { ceł i barier } \\
\text { handlowych }\end{array}$ & $\begin{array}{c}\text { Wspólna } \\
\text { zewnę- } \\
\text { trzna } \\
\text { taryfa } \\
\text { celna }\end{array}$ & $\begin{array}{c}\text { Swobodny } \\
\text { przepływ } \\
\text { czynników } \\
\text { produkcji } \\
\text { wewnątrz } \\
\text { ugrupowania }\end{array}$ & $\begin{array}{c}\text { Harmonizacja } \\
\text { polityki } \\
\text { gospodarczej, } \\
\text { pieniężnej } \\
\text { i kursowej }\end{array}$ & $\begin{array}{c}\text { Unifikacja } \\
\text { polityki } \\
\text { zagranicznej } \\
\text { i obronnej }\end{array}$ \\
\hline $\begin{array}{l}\text { Strefa wolnego } \\
\text { handlu }\end{array}$ & & & & & \\
\hline Unia celna & & & & & \\
\hline Wspólny rynek & & & & & \\
\hline $\begin{array}{l}\text { Unia gospodar- } \\
\text { czo-walutowa }\end{array}$ & & & & & \\
\hline Unia polityczna & & & & & \\
\hline
\end{tabular}

- zjawisko występuje

Rys. 1. Formy międzynarodowych ugrupowań integracyjnych

Źródło: P. Bożyk, J. Misala, Integracja ekonomiczna, Warszawa 2003, s. 38; Przemiany we wspótczesnej gospodarce światowej, red. E. Oziewicz, Warszawa 2006, s. 223.

Jak słusznie zauważa Artur Nowak-Far, unię gospodarczą i walutową należy traktować jako proces bowiem przepisy traktatu z Maastricht określają w jaki sposób ma być ona tworzona. Definiują także podstawowe jej atrybuty w postaci ostatecznej: ,gdy jako jedyna waluta będzie funkcjonować euro i gdy państwa członkowskie będą prowadzić jednolitą politykę pieniężną" ${ }^{\text {"13 }}$. Dla doprowadzenia do nastąpienia tego stanu rzeczy ważne było nie tylko tworzenie, stosowanie i monitorowanie skomplikowanego systemu powiązanych ze sobą norm prawnych, ale także ukształtowanie właściwych ram instytucjonalnych UGiW w celu jak najpełniejszej realizacji celów integracji gospodarczej i walutowej w Unii Europejskiej.

\section{Integracja gospodarcza i walutowa w latach 1950-1970}

Dążenie do integracji gospodarczej i walutowej w Europie Zachodniej uwidoczniło się już na początku lat pięćdziesiątych XX wieku ${ }^{14}$. Na przełomie lat 50. i 60. państwa

13 A. Nowak-Far, Unia Gospodarcza i Walutowa w Europie, Warszawa 2001, s. 1.

14 W Europie po zakończeniu II wojny światowej projekty integracji walutowej i gospodarczej uwidoczniły się już na przełomie lat 40. i 50. XX wieku. Jak wskazuje K. Dyson, po wojnie z inicjatywy amerykańskiej agencji ds. Współpracy Europejskiej administrującej Europejskim Programem Odbudowy, planowano utworzyć europejski bank centralny operujący jedną walutą na wzór amerykańskiej Rezerwy Federalnej. Co więcej, Agencja wypracowała terminarz utworzenia unii monetarnej. Unia miała powstać najpóźniej pod koniec 1951 r., zaś do lipca 1952 r. miała zostać wprowadzona wspólna waluta o nazwie ecu lub europa. Ze względu jednak na rozbieżne interesy państw europejskich po wojnie koncepcja ta nie została zrealizowana. Por. K. Dyson, Elusive Union: The Process of Economic and Monetary Union in Europe, London-New York 1994, s. 60-63. 
członkowskie EWG powoływały specjalne komitety mające na celu wzmocnienie współpracy gospodarczej i walutowej. Na przełomie lat 50. i 60. XX wieku należały do nich: Komitet Walutowy (1958) oraz Komitet Krótkookresowej Polityki Gospodarczej (1960). Ideę wspólnej waluty, mającej stanowić zwieńczenie unii walutowej wysunięto już w 1962 roku w memorandum Komisji Europejskiej z 24 października 1962 roku, (tzw. memorandum Marjolina). Komisja zaproponowała, by unia celna prowadziła do ustanowienia pod koniec lat 60. unii gospodarczej z nieodwoływalnymi sztywnymi kursami walut państw członkowskich. Choć samo memorandum nie spowodowało podjęcia działań zmierzających ku usztywnieniu kursu walut (zdecydowano się oprzeć na systemie Breton Woods, który zapewniał powszechną stabilność w tym zakresie) $)^{15}$, memorandum doprowadziło do przyjęcia nowych rozwiązań instytucjonalnych w obszarze integracji walutowej. W 1964 roku powołano Komitet Prezesów Banków Centralnych Państw Członkowskich, który uzupełnił Komitet Walutowy, utworzony na mocy art. 105 ust. 2 Traktatu EWG ${ }^{16}$. Pomimo, że zadania Komitetu Prezesów były początkowo ograniczone, z czasem rola tego organu rosła. Prace Komitetu, który stał się centrum współpracy walutowej pomiędzy bankami centralnymi państw Europejskiej Wspólnoty Gospodarczej (EWG), doprowadziły do utworzenia i zacieśnienia systemu współpracy na poziomie wspólnotowym ${ }^{17}$. Ponadto w 1965 roku utworzono Komitet Polityki Budżetowej ${ }^{18}$.

Pojawiały się też propozycje utworzenia europejskiego banku centralnego. Jedna z pierwszych tego typu propozycji została zawarta w raporcie członka Parlamentu Europejskiego Philippusa van Campena ${ }^{19}$. W raporcie proponowano utworzenie unii monetarnej i powiązanie narodowych banków centralnych w strukturę federalną. Projekt nie został przyjęty ze względu na sprzeciw Niemiec i niezależnego od nacisków politycznych Bundesbanku. Niemcy, korzystające z silnej marki, nie chciały dzielić wspólnej waluty z państwami takimi jak Francja, w których interwencja państwa w gospodarkę była znaczna, a niezależność banku centralnego od rządu - niewielka ${ }^{20}$.

Pod koniec lat 60-tych coraz śmielej wysuwano ideę przekształcenia EWG w unię gospodarczą i walutową widząc w tym możliwość uniknięcia zagrożeń wynikających z coraz widoczniejszych oznak słabości międzynarodowego systemu walutowego. System z Bretton Woods podlegał wówczas presji związanej z amerykańską polityką w zakresie bilansu płatniczego, która była odbiciem trudności gospodarczych w USA. Symptomy relatywnego osłabienia oddziaływania amerykańskiego na partnerów gospodarczych były widoczne wcześniej, już w czasie prosperity lat 60 . Zdaniem Alana

15 System z Bretton Woods sprawnie funkcjonował w pierwszej połowie lat 60 . XX w. W tym czasie kursy walutowe głównych państw rozwiniętych były stabilne w przedziale $\pm 1 \% \mathrm{w}$ stosunku do kursu parytetowego, co sprzyjało rozwojowi handlu światowego i pogłębianiu integracji państw członkowskich EWG.

16 D. Andrews, The Committee of Central Bank Governors as a source of rules, „Journal of European Public Policy" 2003, Vol. 10, No. 6, s. 956-973.

17 H. K. Scheller, Europejski Bank Centralny. Historia, rola i funkcje, wyd. 2, Franfurt n. Menem 2006, s. 17.

18 Por. E. Apel, European monetary integration 1958-2002, London-New York 1998, s. 25 in.

19 M. Grzesiak, Europejski Bank Centralny, Torun 2004, s. 13.

${ }^{20}$ Ibidem. 
L. Sorokina spadek tempa wzrostu gospodarczego w USA rozpoczął się pod koniec 1966 r. i trwał do połowy 1967 r. Po krótkim okresie ożywienia w połowie 1967 r. ponowny spadek koniunktury nastapił w latach $1969-1970^{21}$. Począwszy od $1971 \mathrm{r}$. Stany Zjednoczone miały ujemny bilans handlowy, natomiast Europa Zachodnia i Japonia odnotowały wysoką nadwyżkę w tym bilansie ${ }^{22}$. O ile w 1953 roku na same tylko Stany Zjednoczone przypadało prawie $30 \%$ światowego eksportu towarów, o tyle pod koniec lat 70. udział USA w eksporcie towarów zmniejszył się do 13\%, co zepchnęło je na drugą pozycję za RFN (16\%). Dużym problemem stała się też wymienialność dolara na złoto, którą „podkopywała” ekspansywna polityka fiskalna i pieniężna USA związana z programem prezydenta Lyndona Johnsona (Wielkie Społeczeństwo) oraz finansowaniem wojny wietnamskiej.

Rosnące rozbieżności w zakresie cen i kosztów prowadzące do coraz liczniejszych kryzysów walutowych i kryzysów bilansu płatniczego zaczęły zagrażać funkcjonowaniu unii celnej, której istnienie z uwagą i niepokojem śledzono w Waszyngtonie. Już w latach 60. XX wieku jeden z badaczy stosunków ekonomicznych pomiędzy USA a EWG - Bruce Club - obserwując powstawanie unii celnej oraz likwidację barier celnych wewnątrz EWG między 1958 a 1968 r. (tab. 1), zauważył, że jeżeli nie zostaną zawarte umowy zabezpieczające dostęp towarów amerykańskich na rynki państw Europy Zachodniej, to protekcjonistycznie nastawione państwa EWG wyprą je ze wspólnego rynku.

Tabela 1

Zmiana wysokości narodowych stawek celnych w obrocie wewnątrz EWG w stosunku do poziomu z dnia 1.01.1955 r. (w \%)

\begin{tabular}{||c|c|c|c||}
\hline \multirow{2}{*}{ Lata } & \multirow{2}{*}{ Zalożenia układu } & \multicolumn{2}{|c|}{ Realizacja } \\
\cline { 3 - 4 } & & artykuly przemyslowe & produkty rolnicze \\
\hline 1.01 .1959 & 90 & 90 & 90 \\
\hline 1.07 .1960 & 80 & 80 & 80 \\
\hline 1.01 .1961 & - & 70 & 75 \\
\hline 1.01 .1962 & 70 & 60 & 65 \\
\hline 1.07 .1962 & - & 50 & 60 \\
\hline 1.07 .1963 & 60 & 40 & 50 \\
\hline 1.01 .1965 & 50 & 30 & 40 \\
\hline 1.01 .1966 & 40 & 20 & 30 \\
\hline 1.07 .1967 & - & 15 & 25 \\
\hline 1.07 .1968 & - & 0 & 0 \\
\hline
\end{tabular}

Źródło: Z. W. Puślecki, Ochrona handlowa Wspólnoty Europejskiej, Poznań 1994, s. 45.

21 A. L. Sorokin, Monetary and Fiscal Policy and Business Cycles in the Modern Era, Lexington Books 1988, s. 63-63, w: B. Mucha-Leszko, Współczesna gospodarka światowa, Lublin 2005, s. 55-56.

${ }^{22}$ Głębokie różnice pomiędzy deficytem bilansu handlowego USA i nadwyżkami po stronie EWG i Japonii nie były w sumie dla gospodarki światowej korzystne. Sytuacja ta była bowiem wykorzystywana przez spekulantów na giełdach walutowych, którzy podbijając kurs jena i marki niemieckiej przyczyniali się tym samym do deprecjacji kursu dolara. Por. Z. W. Puślecki, Ekonomiczne aspekty Zimnej Wojny, w: Zimna Wojna (1946-1989) i jej konsekwencje dla ładu międzynarodowego, Instytut Zachodni, Studia Europejskie nr 15, Poznań 2007, s. 157-185. 
Wspomniane zagrożenia dla funkcjonowania unii celnej były spowodowane w dużej mierze przez ataki spekulacyjne na waluty byłych metropolii europejskich oraz pojawienie się tzw. paradoksu Triffina ${ }^{23}$. Ataki spekulacyjne dotknęły brytyjskiego funta, a następnie franka (w 1968 r.). Pokazały one, że byłe metropolie, mające długookresowe deficyty bilansu płatniczego (obrotów bieżących), zbyt długo broniły się przed dewaluacją waluty z obawy, że przyczyni się to do osłabienia pozycji ich pieniądza jako środka rezerw walutowych innych państw. Kursy funta brytyjskiego i franka (a także marki niemieckiej) były zbyt sztywne, a mechanizm ich korekt nie funkcjonował prawidłowo. Nadmiernie usztywnione kursy walutowe rodziły ataki spekulacyjne, które w przypadku oczekiwanej dewaluacji pozbawiały banki centralne rezerw dewizowych. Co więcej, w latach 60. dostrzeżono tzw. paradoks Triffina. W pewnym uproszczeniu polegał on na tym, że dla rozwoju handlu światowego potrzebna była odpowiednia płynność pieniądza światowego, którym były dolary amerykańskie. Oznaczało to, że potrzebne były deficyty bilansu płatniczego (obrotów bieżących) Stanów Zjednoczonych, dzięki którym dolary przepływały z USA do gospodarki światowej. Z drugiej jednak strony istniała potrzeba nadwyżki lub równowagi bilansu płatniczego USA dla utrzymania wiarygodności wymienialności dolara na złoto po stałym kursie parytetowym. Wzrastająca liczba dolarów w gospodarce światowej, przy prawie niezmiennej ilości rezerw złota utrzymywanych przez amerykański Bank Rezerwy Federalnej, powodowała bowiem, że wymienialność dolarów na złoto po stałym kursie stawała się coraz bardziej nierealna. Próby rozwiązania tego problemu przez emisje specjalnych praw ciagnienia (SDR) kreowanych przez Międzynarodowy Fundusz Walutowy (MFW) nie przyniosły oczekiwanych rezultatów ${ }^{24}$. Można przyjąć, że wszystkie wyżej wymienione czynniki, tj. trudności z wymienialnością dolara na złoto, ataki spekulacyjne i paradoks Triffina przyczyniły się do załamania systemu z Breton Woods na początku lat 70-tych.

Nieco wcześniej, pod koniec lat sześćdziesiątych XX w., w obliczu narastających zagrożeń dla stabilności walutowej w Europie Zachodniej zarysowały się dwa stanowiska odnośnie do utworzenia unii walutowej. Pierwsze z nich prezentowali tzw. ekonomiści. Utrzymywali, że wprowadzenie stałych i nieodwracalnych kursów walutowych nastąpi w wyniku zbliżenia poziomu rozwoju gospodarczego w państwach członkowskich, a unia walutowa powinna zostać utworzona w końcowej fazie realizacji unii gospodarczej. Odmienne stanowisko zajęli monetaryści. Duże znaczenie pokładali oni w unii walutowej, która miała stanowić siłę napędową integracji gospodarczej. Twierdzili oni, że stopniowa redukcja marż wahań kursów walutowych powinna skłonić państwa EWG do koordynacji polityki gospodarczej. W przeciwnym razie mogłyby wystąpić silne napięcia w układzie kursów walutowych ${ }^{25}$.

Jak zauważa J. Bilski różnice pomiędzy monetarystami a ekonomistami „nie miały jedynie teoretycznego charakteru", ale odzwierciedlały ówczesne preferencje gospo-

23 J. J. Michałek, Zarys integracji gospodarczej $i$ walutowej w Europie, w: Mechanizmy funkcjonowania strefy euro, red. P. Kowalski, G. Tchorek, J. Górski, NBP, Warszawa 2010, s. 13-40.

24 Ibidem.

25 J. Bilski, Integracja walutowa do traktatu z Maastricht, w: Integracja europejska. Podręcznik akademicki, red. A. Marszałek, Warszawa 2004, s. 313. 
darcze państw Wspólnoty ${ }^{26}$. Poglądy monetarystów odpowiadały Francji, która dążyła do wzmocnienia franka, czemu miała służyć koordynacja polityki walutowej w ramach EWG. Z kolei po stronie ekonomistów stanęły Niemcy, które dysponując pod koniec lat 60. nadwyżką bilansu płatniczego, przeciwstawiały się osłabieniu dobrej pozycji marki. Napięcie polityczne między Francją i Niemcami wzmagał ponadto kryzys walutowy z 1968 roku, który doprowadził w następnym roku do rewaloryzacji marki niemieckiej i dewaluacji franka francuskiego ${ }^{27}$. Zaburzenia walutowe stanowiły również zjawisko niekorzystne z punktu widzenia wspólnej polityki rolnej, gdyż ceny produktów rolnych były ustalane w dolarach USA. Dopiero jednak w lutym 1969 roku, kilka miesięcy po poważnym kryzysie franka, Komisja Europejska przedstawiła komunikat adresowany do Rady w sprawie sformułowania etapowego planu utworzenia unii gospodarczej i walutowej, zwany też planem Barre'a. Już na tym etapie uwidoczniły się różnice zdań. Kanclerz Niemiec Willi Brandt nawoływał do utworzenia „wspólnoty stabilności”, koordynacji krótko- i średnioterminowej polityki gospodarczej oraz etapowego, ostrożnego budowania unii walutowej. Premier Francji Georges Pompidou stawiał natomiast na konieczność utworzenia wspólnych instytucji i ustanowienia sztywnych kursów walutowych ${ }^{28}$. W tych warunkach zachodnioniemiecki kanclerz W. Brandt przedłożył w grudniu 1969 roku na szczycie rządów i państw Wspólnot Europejskich w Hadze propozycję stworzenia unii walutowej i gospodarczej. Ponieważ plan został przygotowany przez specjalny komitet pod kierownictwem premiera i ministra finansów Luksemburga - Pierre'a Wernera - stąd do historii przeszedł jako ,plan Wernera". Stanowił on próbę kompromisu między stanowiskami monetarystów i ekonomistów. Odwoływał się do zasady paralelizmu między koncepcjami, tzn. zarówno systematycznego pogłębiania współpracy w polityce walutowej, jak i koordynacji polityk gospodarczych ${ }^{29}$. Zakładano w nim stopniową eliminację wahań kursów walutowych, nieodwołalne usztywnienie relacji kursowych, całkowitą liberalizację przepływu kapitału oraz ujednolicenie polityki pieniężnej i harmonizację polityki ekonomicznej. Plan Wernera zawierał także istotne postanowienia instytucjonalne. Zakładano w nich, że w ciągu 10 lat (do 1980 r.) utworzona zostanie unia walutowa, co odbędzie się $\mathrm{w}$ trzech fazach. W ostatnim etapie, projekt przewidywał wprowadzenie wspólnotowego systemu banków centralnych oraz centralnego gremium decyzyjnego w zakresie polityki gospodarczej ${ }^{30}$.

\section{Plan Wernera i Europejski System Walutowy}

Projekt P. Wernera został przedłożony Radzie i Komisji w październiku 1970 roku, a w marcu 1971 roku Rada podjęła decyzję o jego realizacji. Pomimo ambitnych

\footnotetext{
26 Ibidem.

27 Por. E. Thiel, Die Europäische Union. Von der Integration der Märkte zu gemeinsamen Politiken, Opladen 1998, s. 146.

28 S. Płuciennik, RFN w procesie budowy Unii Gospodarczej i Walutowej w Europie, w: Francja i Niemcy - sity napędowe europejskiej integracji, Wrocław 2006, s. 201.

29 Por. E. Thiel, op. cit., s. 150.

30 Por. E. Thiel, op. cit., s. 148.
} 
założeń, wprowadzanie w życie planu Wernera zostało jednak zawieszone w $1974 \mathrm{r}$. Przyczynił się do tego niewątpliwie kryzys gospodarczy państw członkowskich powiązany z załamaniem walutowym, które ,podkopało” znaczenie ówczesnej metody integracji walutowej. Określano ją mianem „węża walutowego". Jej celem było ograniczenie zakresu wahań wzajemnych kursów walut. Metoda ta zyskała na znaczeniu po zawieszeniu wymienialności dolara na złoto i podpisaniu w grudniu $1971 \mathrm{r}$. tzw. umowy waszyngtońskiej (zwanej też umową smithsońską). Zapisano w niej, że dopuszczalne granice wahań kursów walutowych państw członkowskich wobec dolara amerykańskiego nie będą większe niż $2,25 \%$. To zobowiązanie w praktyce zwiększało marżę wahań kursów walut państw członkowskich, co wynikało z ogólnej tendencji w systemie Breton Woods na początku lat siedemdziesiątych XX wieku, do uelastycznienia kursów walutowych. Ta „elastyczność” została jednak w Europie Zachodniej uznana za trudną do pogodzenia nie tylko z założeniami planu Wernera, ale także z rozwojem kluczowej polityki wspólnotowej, którą była wspólna polityka rolna. Z tego też względu, państwa członkowskie Wspólnot podpisały w 1972 roku w Bazylei traktat, zgodnie z którym wahania kursów walut państw uczestniczących nie mogły przekraczać $2,25 \%$, w porównaniu z teoretycznie dopuszczalnym przedziałem $4,5 \%$ wynikającym z pasma wahań każdej waluty $\pm 2,25 \%$ wokół kursu centralnego wobec dolara amerykańskiego. Powstał wówczas tzw. Mechanizm Kursowy (Exchange Rate Mechanizm-ERM), który zwyczajowo był określany jako „wąż w (dolarowym) tunelu”31. W ramach wspomnianego wyżej mechanizmu obronę poszczególnych maksymalnych limitów wahań miały zapewniać interwencje na rynku dolarów amerykańskich i walut wspólnotowych. W praktyce stabilizacja wahań kursów walut polegała na kupowaniu dolara amerykańskiego za najsilniejszą walutę EWG, gdy ta ostatnia osiagnę̧a górny punkt interwencyjny do dolara lub sprzedaż dolarów, gdy najsłabsza z walut EWG osiagnęła dolny punkt.

Wbrew intencjom twórców „wąż walutowy” okazał się mało skutecznym narzędziem dla zapewnienia stabilności walutowej w EWG, a sam skład walut w systemie był zmienny. Już w marcu 1973 r., wskutek upłynnienia kursów walutowych w systemie z Bretton Woods, „wąż” stracił „tunel”, ponieważ kursy wzajemne poszczególnych walut wobec dolara nie były już stabilizowane. Stopniowo narastała niestabilność, związana z opuszczaniem systemu stabilizacji kursów przez niektóre państwa, dewaluacje i rewaluacje kursów ich walut, a także powtarzające się kryzysy walutowe. Przykładem jest Francja, która wycofała się z systemu w styczniu 1974 r., by do niego powrócić w czerwcu 1975 r., i ponownie wycofać się w marcu 1976 roku. Problemem było też ogólne pogorszenie sytuacji gospodarczej na świecie i zmiany podejścia do rozwiązywania problemów ekonomicznych państw takich jak: Francja, Wielka Brytania, Irlandia i Włochy. Uwalniając kursy walutowe (dewaluacja walut) dążyły one do skuteczniejszej walki z bezrobociem i zwiększania konkurencyjności ich gospodarek czemu próbowały przeciwdziałać państwa o silnej walucie tj. RFN, także silnie z nią współpracujące Holandia, Belgia i Dania.

31 A. Nowak-Far, Unia..., s. 25. 
Oceniając projekt Wernera od strony instytucjonalnej należy zauważyć, że stworzył on podwaliny pod dalszy rozwój organów przyszłej unii gospodarczej i walutowej. W kwietniu 1973 r. na mocy rozporządzenia Rady powołano bowiem Europejski Fundusz Stabilności Walutowej (European Monetarny Coordination Fund-EMCF) ${ }^{32}$. Organ ten, któremu nadano osobowość prawną, miał na celu:

- przyczynianie się do stopniowego zawężania marży wahań wzajemnych kursów walut państw członkowskich;

- wspieranie interwencji w walutach państw członkowskich na międzynarodowych rynkach walutowych;

- promowanie systemu rozliczeń między bankami centralnymi w celu osiagnięcia stanu, w którym zarządzanie rezerwami tych banków będzie całkowicie skoordynowane ${ }^{33}$.

Fundusz działał w oparciu o statut. Jego organem naczelnym była Rada Prezesów (Board of Governors) składająca się z członków Komitetu Prezesów Banków Centralnych Państw Członkowskich. Funduszowi nadano kompetencje do administrowania środkami pomocy finansowej dla banków centralnych, przy czym jego decyzje w tym względzie musiały być zgodne z ogólnymi wytycznymi Rady przyjętymi jednomyślnie. Decyzje EMCF-u wykonywał Bank Rozliczeń Międzynarodowych w Bazylei.

EMCF nie spełnił pokrywanych w nim nadziei i to z kilku powodów. Po pierwsze jego działania zostały w praktyce podporządkowane ogólnym wytycznym Rady, działającej w składzie ministrów finansów i gospodarki państw członkowskich EWG (Rada ds. Gospodarczych i Finansowych - ECOFIN) i reprezentującej interesy polityczne państw członkowskich. Uderzało w niezależność krajowych banków centralnych, których prezesi tworzyli organ naczelny funduszu. Po drugie, najważniejsze decyzje walutowe zapadały na forum utworzonego w 1964 roku Komitetu Prezesów Banków Centralnych Państw Członkowskich, którego członkowie, tworzący Radę Prezesów Funduszu, nie widzieli potrzeby podejmowania decyzji w ramach nowego, nieautonomicznego politycznie gremium.

Pomimo, że proces integracji gospodarczej i walutowej wytracił tempo w latach 70 . pojawiały się propozycje stymulacji projektu unii gospodarczej i walutowej poprzez stworzenie adekwatnych struktur instytucjonalnych. Andrzej Komar za najistotniejsze wśród nich uznał raport Leo Tindemansa (styczeń 1976), dwie opinie grupy Optica przedstawione Komisji na podstawie jej zlecenia $(1975,1976)$, opinię wyrażoną przez grupę dziewięciu ekonomistów z różnych europejskich ośrodków naukowych, opublikowany w pismie „The Economist” (tzw. Manifest Dnia Wszystkich Świętych, 1975) ${ }^{34}$ oraz tzw. raport Marjolina (1975) ${ }^{35}$. Na szczególną uwagę zasługują wnioski przedstawione przez grupę Roberta Marjolina oraz raport premiera Belgii Leo Tindemansa. Oba dokumenty powstały w latach 1975-1976. Grupa Marjolina proponowała utworzenie centralnej instytucji bankowej lub systemu banków centralnych odpowiedzial-

32 Rozporządzenie Rady 907/73/EWG z 3.04.1973 r. powolujace do życia Europejski Fundusz Stabilności Walutowej, Dz. U. WE L 89/73.

33 A. Nowak-Far, op. cit, s. 28.

34 Basevi Georgio, et. al., The All Saints Day Manifesto for European Monetary Union, „,The Economist", 1-7 November 1975, s. 33 i n.

35 A. Komar, Europejska Unia Walutowa, Warszawa 1993, s. 104-106. 
nych za zarządzanie polityką monetarną na poziomie wspólnotowym, ustanowienie centrum podejmowania decyzji odpowiedzialnego za prowadzenie polityki gospodarczej i społecznej oraz zdolnego do działania dzięki posiadaniu odpowiednich środków finansowych, a także wprowadzenie środków demokratycznej kontroli, którymi miałby dysponować Parlament Europejski, wybierany w wyborach powszechnych i wyposażony $\mathrm{w}$ uprawnienia prawodawcze ${ }^{36}$. W raporcie Tindemansa zawarto między innymi postulat likwidacji barier w przepływie kapitału w państwach EWG oraz podobnie jak we wcześniejszym dokumencie przygotowanym przez grupę R. Marjolina - powołanie wspólnotowego centrum decyzyjnego kształtującego politykę walutową ${ }^{37}$. Ponadto w Manifeście Dnia Wszystkich Świętych zakładano wprowadzenie wspólnej waluty określanej jako „Europa”, równolegle funkcjonującej z walutami narodowymi i opartej na koszyku walut EWG. Z czasem „Europa” miała wyprzeć waluty narodowe i pozostać jedynym prawnym środkiem płatniczym w EWG. Jednocześnie autorzy manifestu wskazywali na konieczność powstania niezależnego od nacisków politycznych europejskiego banku centralnego, który byłby odpowiedzialny za prowadzenie jednolitej polityki pieniężnej na obszarze wspólnoty. Z kolei grupa Optica uważała, że należy obniżać inflację po to, by uzyskać konwergencję polityk gospodarczych w państwach członkowskich i wprowadzić kursy stake ${ }^{38}$.

Niska skuteczność „węża walutowego" jako instrumentu stabilizowania kursów skłoniła polityków i ekonomistów do poszukiwania nowych rozwiązań. Dewaluacja walut we Włoszech, Francji i Wielkiej Brytanii nie przyniosła ożywienia w eksporcie natomiast przyczyniła się do dalszego wzrostu cen na rynkach krajowych. W związku z powyższym rząd francuski Raymonda Barre'a podją, pod koniec lat 70-tych XX w., działania zmierzające do zwalczania inflacji i utrzymania stałego kursu franka. Zmiana polityki francuskiej stała się podstawą wspólnego wystąpienia niemieckiego kanclerza Helmuta Schmidta i prezydenta Francji Valeriego Giscarda d'Estainga, którzy zaproponowali utworzenie Europejskiego Systemu Walutowego (ESW).

Plan ten został pod względem koncepcyjnym poprzedzony przez kilka propozycji zgłaszanych m.in. przez Jean-Pierre'a Fourcade'a - ministra finansów Francji i Wima Duisenberga - ministra finansów Holandii. Pierwszy z planów przewidywał intensywne korzystanie z interwencji walutowych, zaś w drugim koncentrowano się na wsparciu polityk, które nie powodowały wyjścia poza pasmo nakreślone mechanizmem kursowym $^{39}$. Ostatecznie dzięki poparciu ESW przez głównych polityków Francji i Niemiec, a także poparciu tej idei przez Roya Jenkinsa - przewodniczącego Komisji Wspólnot Europejskich - ESW został przyjęty mocą uchwały Rady Europejskiej z 5 grudnia 1978 r. Państwa EWG zgodziły się na jego utworzenie, licząc na poprawienie stabilności

36 R. Marjolin, et al., Report of the Members of the Study Group ,Economic and Monetary Union 1980”, Commission of the European Communities, Brussels, 8 March 1975, s. 29.

37 Por. European Union, Report by Mr Leo Tindemans. Prime Minister of Belgium, to the European Council, Bulletin of the European Communities, 1/76, Commission of the European Communities, Brussels, s. 19-23.

${ }_{38}$ H. Gronkiewicz-Waltz, Europejska Unia Gospodarcza i Walutowa, wyd. 2, Warszawa 2011, s. 26.

39 Ibidem. 
walutowej, wzrost gospodarczy, zmniejszenie bezrobocia i konwergencję poziomów rozwoju gospodarczego w państwach członkowskich ${ }^{40}$.

ESW zaczął działać od 13 marca 1979 r. z mocą wsteczną od 1 stycznia 1979 roku. Jego funkcjonowanie oparto w większości na instrumentach wykorzystywanych przez „wąż walutowy”. Na konstrukcję Europejskiego Systemu Walutowego składały się:

- europejska jednostka walutowa (European Currency Unit - ECU);

- europejski mechanizm kursowy (Exchange Rate Mechanizm - ERM) ${ }^{41}$;

- system kredytowy wspólnoty ${ }^{42}$.

Jak wskazuje J. Bilski, osią systemów walutowych stała się europejska jednostka walutowa ${ }^{43}$. ECU nie była samodzielną waluta, ale specyficznie skonstruowanym koszykiem walutowym złożonym z określonej liczby jednostek walut państw członkowskich, ustalonej proporcjonalnie do ich potencjału gospodarczego i znaczenia tego potencjału w ugrupowaniu. Pełniła rolę waluty rezerwowej i rozliczeniowej. Była denominatorem mechanizmu kursowego, bowiem dla walut uczestniczących w ESW określano kursy centralne w stosunku do ECU, a z kolei na ich podstawie określano bilateralne kursy centralne, czyli kursy między poszczególnymi walutami.

Zgodnie z uchwałą Rady Europejskiej z 1978 r. centralną rolę w ESW powinno odgrywać ECU, jednak jej rola była ograniczona. Część ekonomistów upatrywała w ECU waluty paralelnej, która miała sukcesywnie zastępować waluty narodowe. Inni przewidywali przejmowanie przez nią funkcji dolara w stosunkach finansowo-walutowych państw wspólnoty. W praktyce, ECU awansowało w latach 80 . XX wieku do roli liczącej się waluty międzynarodowej.

\footnotetext{
40 K. Szelagg, Integracja walutowa w Europie Zachodniej, „Materiały i Studia NBP”2003, nr 166, s. 18 .

${ }^{41}$ Zadaniem ERM było stabilizowanie wahania kursów walut państw ESW. Każda waluta EWG miała ustalony kurs centralny w stosunku do ECU. Od 13 marca 1979 r. do 2 sierpnia 1993 r. dozwolony przedział odchyleń kursowych wynosił zasadniczo $\pm 2,25 \% \mathrm{w}$ stosunku do centralnego parytetu. Dotyczył on walut RFN, Francji, Danii, Holandii, Belgii, Luksemburga, Irlandii. Dla włoskiego lira pasmo wahań było szersze i wynosiło $\pm 6 \%$. Z wyższego przedziału korzystały też waluty państw w późniejszym czasie włączone do mechanizmu kursu walutowego, tj. hiszpańskie peso (od czerwca 1984 r.), brytyjski funt (od października 1990 r.), portugalskie escudo (od kwietnia 1992 r.). Waluty tych państw zyskały marżę $\pm 6 \%$. We wrześniu 1992 r. Wielka Brytania i Włochy wystapiły z systemu, a od sierpnia 1993 r. do walut wszystkich członków systemu (dziewięciu państw) stosowano marżę w wysokości $\pm 15 \%$ (z wyjątkiem relacji marki niemieckiej do guldena holenderskiego, gdzie na mocy bilateralnej umowy utrzymano $\pm 2,25 \%$ ). Zmiany parytetu centralnego mechanizmu kursowego były dokonywane w formie jednomyślnej decyzji państw członkowskich na podstawie zalecenia Komisji i po konsultacji z Komitetem Walutowym (obecnie jest to Komitet Ekonomiczno-Finansowy). Jeżeli odchylenia przekroczyły ustalony przedział, czyli marżę, banki zobowiązane były do interwencji, tj. do zakupywania słabszej waluty w celu podnoszenia jej kursu walutowego albo sprzedaży silniejszej waluty dla obniżenia jej kursu. Por. P. Kalka, Rola RFN..., op. cit., s. 118-119; L. Oręziak, op. cit., s. 219-222.

42 System kredytowy jako składnik ESW polegał na udzielaniu krótko- lub średniookresowych kredytów, przy czym te ostatnie połączone były z kredytem wspomagającym w celu równoważenia bilansu płatniczego. Mechanizm finansowy funkcjonował na podstawie umowy banków centralnych działających w ESW, a za obsługę umów odpowiadał Bank Rozliczeń Międzynarodowych w Bazylei.

43 J. Bilski, Integracja walutowa..., s. 320.
} 


\section{W kierunku Unii Gospodarczo-Walutowej}

Kolejnym etapem na drodze do utworzenia unii gospodarczej i walutowej w Europie było uchwalenie Jednolitego Aktu Europejskiego (JAE), który został podpisany w lutym 1986 roku, i wszedł w życie 1 lipca 1987 roku. Akt ten stanowił sygnał, że następuje dalsza integracja gospodarcza i walutowa, która prowadzi do powstania unii. Świadczą o tym zarówno zapisy dotyczące rynku wewnętrznego, uznanego za obszar bez granic wewnętrznych, w którym jest zapewniony swobodny przepływ towarów, osób, usług i kapitału (art. 13 JAE), jak również zobowiązanie się państw członkowskich do budowy unii gospodarczej i walutowej (art. 18 JAE) oraz przyjęcie ponad dwustu dyrektyw realizujących w praktyce wspólny rynek.

Ośrodki decyzyjne zgodziły się co do tego, że wyeliminowanie granic wewnętrznych w obrębie wspólnego rynku spowoduje zbliżenie gospodarek krajowych i zwiększy stopień integracji gospodarczej wspólnoty. Dostrzegano jednocześnie, że wspólny rynek może wykorzystywać swój potencjał najpełniej pod warunkiem wprowadzenia wspólnej waluty. Integracja gospodarcza i walutowa wymagała jednakże wzmocnienia ram instytucjonalnych, które pod koniec lat 80 . były niewystarczające do realizacji UGiW.

Propozycję zmian w tym zakresie 26 lutego 1988 r. przedstawił zachodnioniemiecki minister spraw zagranicznych Hans Dietrich Genscher. W memorandum (zwanym dalej memorandum Genschera) zawarł propozycje powołania gremium mającego przedstawić opinie na temat zasad rozwoju europejskiego obszaru walutowego oraz projektu stworzenia statutu Europejskiego Banku Centralnego. W dokumencie wypowiedziano się przeciw zobowiązaniu EBC do finansowania narodowych deficytów budżetowych, ponieważ nadanie mu takich uprawnień mogłoby przyczynić się do destabilizacji waluty. Kluczowym celem EBC dla Genschera miało być zapewnienie stabilności pieniądza. Funkcjonowanie centralnej instytucji UGiW miało opierać się na modelu niemieckim, co było zrozumiałe zważywszy na stabilność marki niemieckiej stanowiącej jedną z przyczyn sukcesu gospodarki RFN ${ }^{44}$. Propozycja Genschera spotkała się z mieszanym przyjęciem. Poparł ją kanclerz Niemiec Helmut Kohl, choć początkowo sceptyczny był niemiecki minister finansów Gerhard Stoltenberg. Jego zdaniem proces utworzenia unii walutowej powinien być rozłożony w czasie. Za priorytet uznał on ściślejszą współpracę EWG w zakresie polityki walutowej oraz zacieśnianie współpracy banków walutowych ${ }^{45}$. Z rezerwą do memorandum Genschera odniósł się też Niemiecki Bank Centralny, obawiając się negatywnych skutków w zakresie stabilności cen i waluty. Za utworzeniem Europejskiego Banku Centralnego opowiedzieli się włoski minister finansów Giuliano Amato, a także prezydent Francji François Mitterrand i premier tego państwa Édouard Balladur.

Memorandum Genschera stworzyło podstawy do sformułowania stanowiska niemieckiej prezydencji na posiedzeniu Rady Europejskiej w Hanowerze (27-28 czerwca 1988 r.), gdzie postanowiono o stworzeniu specjalnego komitetu, powierzając mu za-

44 P. Kalka, Rola RFN w rozwoju..., s. 121-122.

45 Stoltenberg, Währungsunion erst auf lange Sicht, „Frankfurter Allgemeine Zeitung”, nr 66, 18 marca 1988, s. 13. 
danie zaproponowania konkretnych etapów realizacji unii gospodarczo-walutowej. Funkcję przewodniczącego powierzono Jacquesowi Delorsowi - przewodniczącemu Komisji Wspólnot i stąd od jego nazwiska komitet określano powszechnie jako Komitet Delorsa ${ }^{46}$.

Organ ten 17 kwietnia 1989 r. przekazał szefom rządów i państw raport na temat etapów tworzenia UGiW. W raporcie unię gospodarczą uznano za obszar gospodarczy składający się z czterech elementów. Pierwszy z nich stanowił jednolity rynek oparty na swobodzie przepływu towarów, usług, osób i kapitału. Kolejne zakładały prowadzenie polityki konkurencji na szczeblu wspólnotowym zapewniającej jednakowe traktowanie produktów z różnych państw członkowskich oraz rozwijanie polityki regionalnej mającej na celu zmniejszanie dysproporcji pomiędzy poszczególnymi obszarami. Ostatnim elementem była koordynacja polityk makroekonomicznych państw członkowskich mająca na celu zapobieżenie tworzeniu się nadmiernych deficytów budżetowych w państwach członkowskich ${ }^{47}$. Z kolei unię walutową zespół pod kierownictwem J. Delorsa określił jako obszar, na którym spełnione są następujące warunki:

- wprowadzenie pełnej i nieodwracalnej wymienialności walut;

- ustanowienie całkowitej swobody przepływu kapitałów oraz integracja rynku finansowego;

- eliminacja marż walutowych oraz nieodwracalne usztywnienie relacji kursowych ${ }^{48}$.

$\mathrm{W}$ raporcie przedstawiono rozwiązania instytucjonalne dla unii gospodarczej i walutowej. Zdecydowano się na ustanowienie centralnej instytucji walutowej o statusie zbliżonym do instytucji wspólnotowych. Banki centralne państw członkowskich miały tworzyć układ określany jako Europejski System Banków Centralnych. System ten miał łączyć narodowe banki emisyjne i Europejski Bank Centralny. W raporcie za cel działania ESBC uznano stabilność cen. System miał być odpowiedzialny za realizację polityki pieniężnej, kursowej, zarządzanie rezerwami, system rozliczeń i koordynację nadzoru bankowego. Określono też organizację systemu. Istotne uprawienia w zakresie polityki gospodarczej uzyskała Rada, która miała prawo wyrażania ogólnych wytycznych. Ich realizację pozostawiono rządom państw członkowskich ${ }^{49}$.

Raport Delorsa, przyjęty na posiedzeniu Rady Europejskiej w Madrycie w czerwcu 1989 r., przewidywał utworzenie UGiW w trzech etapach. Rok później, w grudniu 1990 r. w Strasburgu, zwołano konferencję międzyrządową w celu ustalenia poprawek do Traktatu ustanawiającego Europejską Wspólnotę Gospodarczą, niezbędnych do ustanowienia unii gospodarczej i walutowej. Konferencja ta z kolei doprowadziła do podpisania w 1992 r. w Maastricht Traktatu o Unii Europejskiej (TUE). Traktat ten, w odniesieniu do UGiW, oparto na ustaleniach zawartych w raporcie Delorsa. Postanowiono utworzyć unię gospodarczą i walutową w trzech etapach (tab. 2). W rezultacie do Traktatu ustanawiającego Wspólnotę Europejską wprowadzono nowy tytuł „Polityka

${ }^{46}$ W skład komitetu weszli prezesi krajowych banków centralnych wspólnoty oraz Alexandre Lamfalussy, dyrektor naczelny Banku Rozrachunków Międzynarodowych (BIS), Niels Thygesen, profesor ekonomii z Kopenhagi, Miguel Boyer, prezes Banco Exterior de España i Frans Andriessen, członek Komisji Europejskiej.

47 Integracja Europejska..., s. 326.

48 Ibidem.

49 H. Gronkiewicz-Waltz, Europejska Unia..., s. 35. 
gospodarcza i walutowa". Unii walutowej i gospodarczej poświęcono w nim dwa pierwsze rozdziały, obejmujące art. $102 \mathrm{a}-104 \mathrm{c}$ oraz $105-109 \mathrm{~m}$. Istotne były też postanowienia zawarte w czterech protokołach. Należały do nich:

- Protokół w sprawie Europejskiego Systemu Banków Centralnych,

- Protokół o statucie Europejskiego Instytutu Monetarnego,

- Protokół o procedurze przy występowaniu nadmiernego deficytu,

- Protokół o kryteriach konwergencji wg art. 109j Traktatu o utworzeniu Wspólnoty Europejskiej.

Tabela 2

Etapy dochodzenia do unii gospodarczej i walutowej w latach 1990-2002

\begin{tabular}{|c|c|l||}
\hline \hline Etapy & Czas realizacji & \multicolumn{1}{c||}{ Zalożone cele } \\
\hline I & $1.07 .1990-31.12 .1993$ & $\begin{array}{l}\text { - swobodny przepływ kapitału między państwami członkowskimi państw } \\
\text { członkowskich, } \\
- \text { ściślejsza koordynacja polityki gospodarczej, } \\
- \text { ściślejsza współpraca między bankami centralnymi. }\end{array}$ \\
\hline II & $1.01 .1994-31.12 .1998$ & $\begin{array}{l}\text { - zbieżność polityki gospodarczej i pieniężnej państw członkowskich, } \\
- \text { utworzenie Europejskiego Instytutu Walutowego. }\end{array}$ \\
\hline III & $1.01 .1999-30.06 .2002$ & $\begin{array}{l}\text { - ustanowienie Europejskiego Banku Centralnego, } \\
- \text { sztywne kursy walutowe } \\
- \text { wprowadzenie wspólnej waluty. }\end{array}$ \\
\hline \hline
\end{tabular}

Źródło: Unia Europejska. Organizacja i funkcjonowanie, red. M. Cini, tłum. G. Dąbkowski, Warszawa 2007, s. 443.

W pierwszym etapie tworzenia UGiW (1990-1993) zniesiono kontrolę wymiany walut i wprowadzono pełną swobodę przepływu kapitału. Podjęto wysiłki nakierowane na eliminowanie rozbieżności polityki gospodarczej państw członkowskich oraz usuwanie przeszkód utrudniających integrację finansową. Duże znaczenie odegrała decyzja Rady z 12 marca 1990 roku w sprawie stopniowego zbliżania polityki gospodarczej i wyników pracy w czasie pierwszego etapu unii gospodarczej i walutowej ${ }^{50}$. Uregulowano w niej zagadnienie nadzorowania wszelkich aspektów polityk gospodarczych państw członkowskich. Wzięto pod uwagę takie kryteria jak: stabilność cen, zdrowie finansów publicznych, równowaga bilansu płatniczego i konkurencyjność gospodarek. Wielostronny nadzór wykonywany był przez Radę na podstawie raportów Komisji przygotowywanych przez Komitet Monetarny z udziałem Komitetu Polityki Gospodarczej. W zakresie polityki pieniężnej poszerzono zadania Komitetu Prezesów Banków Centralnych Państw Członkowskich. Rada powierzyła Komitetowi prowadzenie konsultacji dotyczących zasad i kierunku polityki zagranicznej, stabilności rynku i instytucji finansowych oraz innych spraw będących w kompetencji banków centralnych. Ogólnie rzecz ujmując, obowiązki Komitetu koncentrowały się w głównej mierze na prowadzeniu konsultacji i wspieraniu koordynacji polityki pieniężnej państw członkowskich w dążeniu do osiagnięcia stabilności cen. Ponadto Komitet zyskał możliwość

50 Decyzja Rady 90/142/EWG z 12 marca 1990 roku w sprawie stopniowego zbliżania polityki gospodarczej $i$ wyników pracy w czasie pierwszego etapu unii gospodarczej $i$ walutowej, Dz. U. WE 1990 L 78, s. 25. 
formułowania opinii dotyczących polityki pieniężnej i kursowej, które były następnie kierowane do rządów państw członkowskich i do Rady, a także uprawienie do tworzenia podkomitetów, zajmujących się polityką pieniężną, dewizową i nadzorem bankowym oraz grup roboczych.

Etap drugi (1994-1998) miał charakter przejściowy i obejmował utworzenie podstawowych instytucji i struktur organizacyjnych UGiW. Zapoczątkowany został przez utworzenie Europejskiego Instytutu Walutowego (EIW) w dniu 1 stycznia 1994 roku. EIW zaprojektowano jako organ tymczasowy, odpowiedzialny za przygotowanie trzeciego etapu UGiW. Europejski Instytut Walutowy zastąpił Komitet Prezesów Banków Centralnych Państw Członkowskich, który przygotowywał UGiW w latach 1990-1993. Od 1994 r. wspomniany Komitet utracił niezależność, stając się organem zarządzającym (Radą) EIW.

Członkami Instytutu były narodowe banki państw członkowskich, a on sam przejął zadania Komitetu Prezesów Banków Centralnych oraz Europejskiego Funduszu Współpracy Walutowej. Jego siedzibą był Frankfurt nad Menem, a pierwszym prezesem został Alexandre Lamfalussy. Instytut działał w oparciu o statut, miał osobowość prawna, a jego organem zarządzającym była Rada. Składała się ona z prezesa wybieranego jednomyślnie na okres trzech lat przez przedstawicieli państw członkowskich na szczeblu szefów państw lub rządów oraz gubernatorów narodowych banków centralnych, z których każdy miał jeden głos. Decyzje w Radzie podejmowano zwykłą większością głosów ${ }^{51}$.

Zgodnie z art. 117 Traktatu ustanawiającego Wspólnotę Europejską (TWE) do głównych zadań EIW należało: zacieśnianie współpracy banków centralnych i wzmacnianie koordynacji polityki pieniężnej oraz prowadzenie niezbędnych przygotowań do ustanowienia ESBC, wprowadzenia wspólnej polityki pieniężnej, utworzenia wspólnej waluty na trzecim etapie UGiW. W celu realizacji niniejszych zadań EIW:

- przygotowywał zestaw instrumentów i procedur prowadzenia wspólnej polityki pieniężnej strefy euro;

- opracowywał ramy dla prowadzenia operacji walutowych oraz utrzymywania i zarządzania oficjalnymi rezerwami zagranicznymi państw członkowskich należących do strefy euro;

- opracowywał specyfikację techniczną i projektową banknotów euro.

EIW współpracował z instytucjami i organami wspólnoty, zwłaszcza z Komisją i Komitetem Walutowym, w przygotowaniu trzeciego etapu UGiW. Do jego obowiązków należało m.in. opracowanie scenariusza przejścia na wspólną walutę, opracowanie ram współpracy między strefą euro a innymi państwami UE w dziedzinie polityki pieniężnej i kursu walutowego (ERM II), monitorowanie postępów państw członkowskich w spełnianiu warunków uczestnictwa w $\mathrm{UGiW}^{52}$. Do istotnych wyda-

51 Protokol on the Statue of the European Monetary Institute, http://europa.eu.int/en/record/ $\mathrm{mt} /$ protocol.html, odczyt z dnia 10 marca $2013 \mathrm{r}$.

52 Należy podkreślić, że członkostwo w UE nie oznacza automatycznie uczestnictwa w strefie euro. Do strefy euro mogą należeć tylko te państwa członkowskie, które spełniają warunki konieczne dla przyjęcia wspólnej waluty. Są to: wysoki stopień trwałej konwergencji (konwergencja gospodarcza) oraz zgodność krajowych przepisów prawnych z postanowieniami Traktatu dotyczącymi UGiW (konwergencja prawna). W latach 90. kryteria konwergencji nominalnej zostały zawarte w art. 121 
rzeń w drugim etapie realizacji UGiW należały ponadto ustalenia dotyczące wspólnej waluty - euro, uzgodnienie Paktu stabilności i wzrostu wraz z nowym mechanizmem wymiany walut (ERM II), oraz doprowadzenie do utworzenia Europejskiego Banku Centralnego.

Inspiracją dla symbolu euro była litera ypsilon. Ważne też było symboliczne podkreślenie wagi kontynentu europejskiego (,e” to pierwsza litera słowa Europa). W listopadzie 1994 r. Rada Europejskiego Instytutu Walutowego zdecydowała, że banknoty euro będą występować w siedmiu nominałach w sekwencji 1-2-5, 10 i 100 euro, 20 i 200 euro oraz 5, 50 i 500 euro. Tę samą sekwencję zastosowano do monet euro: 1 cent, 10 centów i 1 euro, 2 centy, 20 centów i 2 euro oraz 5 centów i 50 centów. Decyzję w tej sprawie podjęła Rada UE ds. Gospodarczych i Finansowych (Ecofin) ${ }^{53}$. Rok później w grudniu 1995 r. na posiedzeniu w Madrycie Rada Europejska potwierdziła, że trzeci etap UGiW rozpocznie się 1 stycznia 1999 roku. Jednocześnie ogłoszono oficjalnie nazwę wspólnej waluty, czyli „euro”, a także kolejność działań prowadzących do jej wprowadzania. Scenariusz ten oparto na szczegółowych wytycznych Europejskiego Instytutu Walutowego ${ }^{54}$.

W grudniu 1995 roku EIW zlecono również rozpoczęcie prac nad przygotowaniem przyszłych relacji pieniężnych i kursowych pomiędzy euro a walutami państw spoza

ust. 1 Traktatu WE. Należały do nich: wysoki stopień stabilności cen (krajowa stopa inflacji nie może przekraczać o więcej niż 1,5 pkt proc. stopy inflacji trzech najlepszych pod tym względem państw UGiW), stabilność kursu walutowego (uczestnik UGiW przez dwa lata nie może dewaluować własnej waluty względem któregoś z państw UGiW), trwały charakter konwergencji długoterminowych stóp procentowych (nie mogą one przekraczać o więcej niż 2 pkt proc. przeciętnej dla trzech najlepszych państw pod tym względem w UGiW), niski dług publiczny (nie może przekroczyć $60 \%$ nominalnego PKB państwa chcącego przystapić do UGiW) oraz niski deficyt budżetowy (nie może przekroczyć $3 \%$ PKB państwa zamierzającego dołączyć do strefy). Po wejściu w życie traktatu lizbońskiego kryteria konwergencji nominalnej zostały uregulowane w art. 126 i 140 TFUE, Protokole w sprawie kryteriów konwergencji oraz Protokole w sprawie procedury dotyczącej nadmiernego deficytu. Kryterium konwergencji prawnej wymaga z kolei zgodności przepisów poszczególnych państw członkowskich z art. 130 i 131 TFUE oraz statutem ESBC i EBC. Kryterium to obejmuje: niezależność instytucjonalną, finansową i personalną krajowego banku centralnego (art. 130 TFUE), zapewnienie przez kraj członkowski zgodności prawodawstwa krajowego z TFUE i statutem ESBC i EBC (art. 131 TFUE), spójność celów banku centralnego z celami wynikającymi w art. 121 ust. 1 TFUE oraz art. 2 statutu ESBC i EBC. Ponadto art. 140 ust. 1 TFUE zobowiązuje Komisję i EBC do uwzględnienia w ich ocenie gotowości danego kraju do przyjęcia wspólnej waluty wielu innych czynników, w tym: stopnia integracji rynków, równowagi na rachunku bieżącym, a także oceny kształtowania jednostkowych kosztów pracy i innych wskaźników cen. Na temat nominalnych i prawnych kryteriów konwergencji zob.: D. M. Mazur, M. J. Mazur, Europejski Bank Centralny a rozszerzenie Unii Europejskiej, Rzeszów 2007, s. 195-203; K. Kwapień, Z. Wójcik. Euro. Wspólna waluta europejska, Warszawa 2011, s. $16-17$.

53 Pod szczególną rozwage poddano kwestię wprowadzenia banknotu o wysokim nominale 500 euro. Za taką decyzją przemawiał argument, że przed wymianą pieniądza w sześciu krajach strefy euro (Austrii, Belgii, Holandii, Luksemburgu, Niemczech i Włoszech) istniały - i były coraz częściej używane - banknoty krajowe o wartości między 200 i 500 euro. Na przykład w 2000 r. zapotrzebowanie na banknoty tysiącmarkowe (równowartość 511 euro) było 15 razy wyższe niż w 1975 r.; na ten nominał przypadało 34\% łącznej wartości banknotów DM znajdujących się w obiegu. Zob.: Jak powstawało euro - nasz pieniądz. Krótka historia banknotów i monet euro, Europejski Bank Centralny, Frankfurt n. Menem 2007, s. 12.

54 Por. Wymiana pieniądza na wspólnq walutę, Europejski Instytut Walutowy 1995. 
euro. W rezultacie jego prac w 1996 r. Instytut przedstawił Radzie Europejskiej raport stanowiący podstawę uchwały Rady Europejskiej w sprawie zasad i podstawowych elementów nowego mechanizmu kursowego ERM II ${ }^{55}$. Dokument ten został przyjęty w czerwcu 1997 roku $^{56}$. Ponadto w czerwcu 1997 r. Rada Europejska przyjęła Pakt stabilności i wzrostu, który miał na celu zapewnienie dyscypliny budżetowej w UGiW. Pakt składał się z trzech instrumentów prawnych: uchwały Rady Europejskiej i dwóch rozporządzeń, uzupełnionych i rozszerzonych deklaracją Rady z 1998 r. $^{57}$

Szczególnie znaczącą rolę EIW odegrał w budowie struktury instytucjonalnej UGiW, zwłaszcza, że w czerwcu 1998 roku powstał Europejski Bank Centralny. Podstawę dla utworzenia tej instytucji stanowił raport przygotowany przez Europejski Instytut Walutowy w 1997 roku. Dokument ten był poświęcony ramom operacyjnym w jakich miał działać bank centralny Unii Europejskiej ${ }^{58}$. Przedstawiono w nim instrumenty prowadzenia przez Europejski Bank Centralny jednolitej polityki monetarnej oraz instrumenty realizacji operacji kredytowych. Określił też warunki postawione instytucjom finansowym oraz jednostkom finansów publicznych, aby mogły one otwierać rachunki w EBC i narodowych bankach centralnych, a także uczestniczyć w ramach jednolitej polityki pieniężnej ${ }^{59}$. Tworzenie EBC nastręczało wielu problemów natury technicznej. Dotyczyły one m.in. doboru instrumentów i metod działania, określenia strategii polityki monetarnej banku, czy kwestii szczegółowych jak: sposób przeprowadzania interwencji na rynkach walutowych. Podstawowe trudności wiązały się z wyborem modelu, który miał przyjać EBC i ESBC, a także tym, kto ma zostać prezesem Banku. Wiele wątpliwości budziło także ustalenie siedziby EBC.

Sygnatariusze umowy z Maastricht mieli do wyboru dwa, powojenne modele bankowości centralnej - anglo-francuski albo niemiecki. W pierwszym bank centralny realizował jednocześnie kilka celów, przy czym cel stabilności pieniądza uznawano za

55 Europejski Mechanizm Kursowy II (ERM II) jest wielostronnym systemem stałych, ale dostosowywanych kursów walutowych, z ustalonym kursem centralnym i standardowym pasmem wahań $\pm 15 \%$. Polityka gospodarcza państw uczestniczących w systemie powinna być spójna z przyjętym kursem centralnym stabilności cenowej w danym państwie członkowskim lub w strefie euro. Mechanizm kursowy ERM II opiera się na wielostronnej umowie między danym państwem członkowskim, krajami członkowskimi strefy euro, EBC a innymi państwami członkowskimi, uczestniczącymi w mechanizmie. W ramach tej umowy decyzje dotyczące kursów centralnych podejmowane są w drodze wzajemnego uzgodnienia między uczestnikami mechanizmu, w tym EBC. Możliwe jest oficjalne uzgodnienie pasma wahań węższego niż standardowe na prośbę danego państwa członkowskiego spoza strefy euro.

56 Uchwała Rady Europejskiej z dn. 16 czerwca 1997 r. w sprawie ustanowienia mechanizmu kursów walutowych $w$ ramach trzeciego etapu unii gospodarczej $i$ walutowej, Dz. U. WE C 286, 2.08.1997 r., s. 5.

57 Uchwała Rady Europejskiej w sprawie Paktu stabilności i wzrostu, Amsterdam, 17 czerwca 1997 r., Dz. U. WE C 236, 2.08.1997, s. 1; rozporządzenie Rady (WE) nr 1466/97 z dnia 7 lipca 1997 r. o wzmocnieniu nadzoru pozycji budżetowych oraz nadzoru $i$ koordynacji polityk gospodarczych, Dz. U. WE L 209, 2.08.1997, s. 1; rozporządzenie Rady (WE) nr 1467/97 z dnia 7 lipca 1997 r. o przyspieszeniu $i$ wyjaśnieniu zasad stosowania procedur nadmiernego deficytu Dz. U. WE L 209, 2.08.1997, s. 6.

58 The single monetary policy in Stage Three: Specification of the operational framework, European Monetary Institute, Frankfurt Am. Main, January 1997, http://www.ecb.int/bt/p5-tc.htm, odczyt $\mathrm{z}$ dn. 14.03.2012 r.

59 M. Grzesiak, Europejski..., s. 32-33. 
występujący wśród, a nie ponad innymi. Inną cechą modelu anglo-francuskiego była dependencja banku centralnego od działań rządu, reprezentowanego najczęściej przez ministra finansów. Powyższy model na początku lat 90. lansowany był przez Francję, którą na konferencjach szefów państw lub rządów państw członkowskich reprezentował jej ówczesny prezydent François Mitterrand. Francja dążyła do osiagnięcia dwóch strategicznych celów i przez to znacznego wzmocnienia swojej pozycji w kształtującym się systemie politycznym Unii Europejskiej. Pierwszym z nich było roztoczenie kontroli nad polityką monetarną w UE. Drugim było ograniczenie wpływów niemieckiego banku centralnego, a przez to osłabienie siły oddziaływania Niemiec w zakresie polityki monetarnej. Miało to nastąić przez usytuowanie przedstawicieli Francji w EBC lub bardziej wyraźne poddanie Rady w składzie ministrów ds. gospodarczych i finansowych (tzw. ECOFIN) kontroli ze strony Paryża. Wizja Francji była naturalnym przedłużeniem rozwiązań właściwych francuskimu bankowi centralnemu, który nigdy w swojej historii, sięgającej początków XIX w., nie był niezależny od władzy centralnej $^{60}$.

Stanowisko Francji spotkało się z odporem Niemiec, stawiających na niezależność EBC, co miało swoje źródło w silnej pozycji jaką Bundesbank odgrywał względem władz federalnych w sprawach dotyczących polityki monetarnej, jak również znacznego prestiżu jakim cieszył się niemiecki bank centralny. Przez kilkadziesiąt lat skutecznie bronił silnej pozycji marki niemieckiej, co przydało jej znaczenia jako drugiej waluty rezerwowej na świecie. O ile zwolennikiem niezależnej europejskiej instytucji bankowej był kanclerz Niemiec Hemut Kohl, o tyle jednak Bundesbank z trudem zaakceptował tę ideę. Źródłem obaw Bundesbanku było przeświadczenie, że dążenie do unii monetarnej wiąże się z ryzykiem zwiększenia inflacji w Europie Zachodniej. Karl-Otto Pöhl, prezes Bundesbanku, wskazywał w związku z tym na konieczność zagwarantowania EBC monopolu w zakresie kreacji wspólnego pieniądza i niezależność od nacisków politycznych.

Stanowisko Bundesbanku miało decydujący wpływ na ostateczny kształt, jaki przyjął system instytucjonalny UGiW. Francja uznała niezależność EBC jedynie w obawie przed wycofaniem się Niemiec z UGiW, choć francuskie kręgi finansowe liczyły na możliwość wpływania na działalność EBC za pomocą Rady Europejskiej jako gremium mającego pewne możliwości wpływania na kształt systemu politycznego Unii Europejskiej. Ostatecznie EBC pod względem organizacyjnym został oparty na Niemieckim Banku Federalnym. Układ organów EBC, pierwotnie wskazany w art. 107 ust. 3 TWE, oparty na Radzie Prezesów i Zarządzie przypominał żywo strukturę Bundesbanku, tworzonego przez Radę Banku Centralnego, Zarząd oraz krajowe banki centralne. Rada Prezesów EBC miała składać się z członków Zarządu i prezesów narodowych banków centralnych, a sam Zarząd - z przewodniczącego, wiceprzewodniczącego oraz czterech dalszych członków. Wyłanianie składu Zarządu miało należeć do szefów rządów i państw, którzy podejmowaliby decyzje na wniosek Rady i po konsultacji z Parlamentem Europejskim. Również kompetencje Rady Prezesów i Zarządu EBC zostały ukształtowane na wzór ich niemieckich odpowiedników. Rada Prezesów

${ }^{60}$ Por. M. Marshall, The Bank. The birth of Europe's Central Bank and the rebirth of Europe's power, London 1999, s. 133 i n. 
była odpowiedzialna za prowadzenie polityki monetarnej (zwłaszcza decyzji o podstawowych stopach procentowych oraz wytycznych niezbędnych dla realizacji polityki pieniężnej). Należy dodać, że wszystkie tego typu działania w Niemczech spełnia Rada Banku Centralnego ${ }^{61}$.

Również Europejski System Banków Centralnych został w znacznej mierze oparty na doświadczeniach niemieckich. Zarówno ESCB jak również EBC zapewniono niezależność, czemu silnie przeciwstawiała się Francja, gdzie od początku XIX w. obowiązywała tradycja podporządkowania banku centralnego (Banque de France) państwu. Niezależność ta przybrała, wzorem niemieckim, dwie formy. Pierwszą była niezależność personalna, o której decydowały postanowienia traktatu z Maastricht o długości kadencji członków Rady, powoływaniu i pozbawianiu urzędów członków Zarządu i Rady EBC. W traktacie z Maastricht przyjęto, za ustawą o Niemieckim Banku Federalnym, regułę długich kadencji, które sprzyjają niezależności urzędników sprawujących swoje funkcje. Tak jak w ustawie niemieckiej, w Protokole o statucie ESBC i EBC przewidziano długie, ośmioletnie okresy kadencji dla członków Zarządu, a dla prezesów narodowych banków centralnych - co najmniej 5 lat ${ }^{62}$.

Oprócz sporów odnośnie do modelu bankowości francuskiej duże znacznie w czasie powstawania EBC miały dyskusje na temat jego siedziby oraz pierwszej prezesury. Stronami ożywionej debaty były w głównej mierze Francja i Niemcy, motywowane w swojej polityce dążeniem do osiagnnięcia decydującego wpływu na kształt polityki walutowej, ale również wzmacniania swojego prestiżu na arenie międzynarodowej. W kwestii siedziby Niemcom udało się przeforsować Frankfurt nad Menem. W przekazie kierowanym do społeczeństwa niemieckiego euro ukazywano jako zmodyfikowaną markę, a Europejski Bank Centralny jako instytucję przypominającą Bundesbank. Co prawda wysuwano też propozycję Amsterdamu na europejską ,stolicę bankową”, jednak zdecydowana postawa kanclerza H. Kohla zadecydowała o wyborze Frankfurtu.

Jeszcze trudniejszym problemem był wybór pierwszego prezesa EBC. Początkowo, w 1993 r., kandydatem na to stanowisko był Holender Willem (Wim) Duisenberg. Ostatecznie jednak zrezygnował, koncentrując się na sprawowaniu funkcji prezesa holenderskiego banku centralnego. Trzy lata później w 1996 r. kandydatura Duisenberga ponownie została wysunięta. Poparli ją zarówno prezes Bundesbanku - Hans Tietmeyer - jak również ustępujący przewodniczący EIW - Alexandre Lamfalussy. Kandydatura W. Duisenberga była kompromisem wiążącym się z faktem, że ze względu na rywalizację Niemiec i Francji w zakresie UGiW nie chciano decydować się ani na kandydata $z$ Niemiec, ani też z Francji ${ }^{63}$. Ten stan rzeczy zmienił się w listopadzie 1997 r. w związku z przedstawieniem przez Jacquesa Chiraca i Lionela Jospina kandydatury Jeana-Claude Tricheta. Konflikt pomiędzy stroną niemiecką a francuską został częściowo zażegnany dopiero w 1998 r., kiedy to W. Duisenberg porozumiał się z J. Chiracem, odnośnie do ustąpienia ze stanowiska w połowie swojej ośmioletniej kadencji. Ustalono, że po jego rezygnacji na stanowisko prezesa EBC

61 J. Viebig, Der Vertrag von Maastricht. Die Position Deutschlands und Frankreichs zur Europäichen Wirtschafts- und Währungsunion, Schäffer-Poeschel Verlag, Stuttgart 1999, s. 437.

${ }^{62}$ Ibidem, s. 452.

63 M. Marshall, The Bank..., s. 50 i n. 
zostanie wybrany Jean-Claude Trichet, zaś Niemcy poprą Christiana Noyera na stanowisko wiceprezesa ${ }^{64}$.

Oficjalnie 25 maja 1998 r. rządy 25 państw członkowskich mianowały prezesa, wiceprezesa i czterech stałych członków Zarządu EBC. Sześcioosobowy organ uzyskał nominację z dniem 1 czerwca 1998 r. (jest to jednocześnie data jego ustanowienia). Zgodnie z art. 123 ust. 2 TWE zlikwidowano Europejski Instytut Walutowy. Europejski Bank Centralny wraz z bankami centralnymi państw UE stworzył Europejski System Banków Centralnych, a razem z bankami emisyjnymi państw wchodzących w skład UGiW tzw. Eurosystem.

1 stycznia 1999 r. rozpoczął się trzeci, ostatni etap tworzenia UGiW. Tego dnia ustalono nieodwołalne kursy wymiany walut jedenastu państw członkowskich, które przystapiły do unii walutowej. Rozpoczął się proces wprowadzania nowej waluty, który podzielono na dwie fazy. W pierwszej, trwającej od 1 stycznia 1999 r. do 31 grudnia 2001 r. ustalono nieodwołalne kursy walutowe walut narodowych do euro, które w stosunku 1:1 zastapiło ecu po kursie z 31 grudnia 1998. Druga faza trwała od 1 stycznia 2002 r. do 30 czerwca 2002 r. Wprowadzono wówczas do obiegu w formie fizycznej euro (banknoty i monety), które pozostawały w obiegu wspólnie z walutami krajowymi do 30 czerwca 2002 r. Od 1 lipca 2002 r. jedynym środkiem cyrkulacji i środkiem płatniczym w UE stało się euro, natomiast waluty narodowe wycofano z obiegu ${ }^{65}$. W $2001 \mathrm{r}$. do strefy euro, na mocy art. 122 ust. 2 TWE oraz właściwej decyzji Rady, dołączyła Grecja, a bank centralny tego państwa dołączył do Eurosystemu ${ }^{66}$. W dalszej kolejności do strefy euro dołączyły: Słowenia - pierwsze spośród tzw. „nowych” państw UE (1 stycznia 2007 r.), Cypr i Malta (1 stycznia 2008 r.), Słowacja (1 stycznia 2009 r.) oraz Estonia (1 stycznia 2011 r.). Poniżej w tabeli 3 przedstawiono rozwój idei integracji gospodarczej i walutowej w Europie.

Tabela 3

Kształtowanie się unii gospodarczej i walutowej oraz rozwój jej organów w latach 1962-2011

\begin{tabular}{||l|l||}
\hline \multicolumn{1}{|c|}{ Data } & \multicolumn{1}{|c||}{ Wydarzenie } \\
\hline \multicolumn{1}{|c||}{1} & \multicolumn{1}{|c||}{2} \\
\hline Październik 1962 & $\begin{array}{l}\text { Pierwsza propozycja stworzenia unii gospodarczej i walutowej (memorandum Marjo- } \\
\text { lina), przedstawiona przez Komisję Europejską. }\end{array}$ \\
\hline Maj 1964 & $\begin{array}{l}\text { W celu zinstytucjonalizowania współpracy banków centralnych Europejskiej Wspól- } \\
\text { noty Gospodarczej (EWG) zawiązany zostaje Komitet Prezesów Banków Centralnych } \\
\text { Państw Członkowskich EWG. }\end{array}$ \\
\hline Luty 1969 & $\begin{array}{l}\text { Komisja przedstawia komunikat adresowany do Rady w sprawie sformułowania eta- } \\
\text { powego planu utworzenia unii gospodarczej i walutowej, tzw. plan Barre'a. }\end{array}$ \\
\hline Październik 1970 & $\begin{array}{l}\text { Ogłoszenie planu Wernera w sprawie stworzenia unii gospodarczej i walutowej do } \\
\text { 1980 r. }\end{array}$ \\
\hline Marzec 1971 & Rada podejmuje decyzję o realizacji planu Wernera. \\
\hline
\end{tabular}

64 Ibidem, s. 180-185.

65 Integracja europejska..., op. cit., s. 327-328.

66 Decyzja Rady 2000/427/WE z dnia 19 czerwca 2000 r. zgodnie z art. 122 ust. 2 Traktatu w sprawie przyjęcia wspólnej waluty przez Grecję, Dz. U. WE, L 167 z dn, 7.07 .2000 r., s. 20. 


\begin{tabular}{|c|c|}
\hline 1 & 2 \\
\hline Marzec 1972 & $\begin{array}{l}\text { Ustanowienie wspólnej polityki kursowej państw członkowskich EWG, zawężającej } \\
\text { pasmo dopuszczalnych wahań kursów ich walut (tzw. „wąż walutowy”). }\end{array}$ \\
\hline Kwiecień 1973 & Powołanie Europejskiego Funduszu Współpracy Walutowej. \\
\hline Marzec 1975 & $\begin{array}{l}\text { Raport Marjolina. Grupa pod przewodnictwem Roberta Marjolina zaproponowała } \\
\text { utworzenie centralnej instytucji bankowej lub systemu banków centralnych odpowie- } \\
\text { dzialnych za zarządzanie polityką monetarną na poziomie wspólnotowym. }\end{array}$ \\
\hline Listopad 1975 & $\begin{array}{l}\text { Manifest Dnia Wszystkich Świętych - konieczność wprowadzenia waluty określanej } \\
\text { jako "Europa", równolegle funkcjonującej z walutami narodowymi i opartej na koszy- } \\
\text { ku walut EWG. }\end{array}$ \\
\hline 1976 & $\begin{array}{l}\text { Raport Tindemansa-postulat likwidacji barier w przepływie kapitału w krajach EWG } \\
\text { oraz powołania wspólnotowego centrum decyzyjnego kształtującego politykę walu- } \\
\text { tową. }\end{array}$ \\
\hline Marzec 1979 & Utworzenie Europejskiego Systemu Walutowego. \\
\hline Luty 1986 & Podpisanie Jednolitego Aktu Europejskiego. \\
\hline Luty 1988 & $\begin{array}{l}\text { Memorandum Genschera - propozycja powołania gremium mającego przedstawić } \\
\text { opinię na temat zasad rozwoju europejskiego obszaru walutowego oraz projektu stwo- } \\
\text { rzenia statutu Europejskiego Banku Centralnego. }\end{array}$ \\
\hline Maj 1989 & Raport Delorsa, którego zadaniem jest urzeczywistnienie UGiW. \\
\hline Czerwiec 1989 & Rada Europejska uzgadnia wprowadzenie UGiW w trzech etapach. \\
\hline Lipiec 1990 & Początek pierwszego etapu UGiW. \\
\hline Grudzień 1990 & $\begin{array}{l}\text { Zwołanie konferencji międzyrządowej odpowiedzialnej za przygotowanie drugiego } \\
\text { i trzeciego etapu UGiW. }\end{array}$ \\
\hline Luty 1992 & Podpisanie Traktatu o Unii Europejskiej (traktat z Maastricht). \\
\hline Październik 1993 & $\begin{array}{l}\text { Wybór Frankfurtu nad Menem na siedzibę Europejskiego Instytutu Walutowego } \\
\text { (EIW) i stworzenie urzędu Prezesa EIW. }\end{array}$ \\
\hline Listopad 1993 & Wejście w życie Traktatu o Unii Europejskiej. \\
\hline Styczeń 1994 & $\begin{array}{l}\text { Rozpoczęcie drugiego etapu tworzenia UGiW i utworzenie Europejskiego Instytutu } \\
\text { Walutowego. }\end{array}$ \\
\hline Grudzień 1995 & $\begin{array}{l}\text { Na posiedzeniu w Madrycie Rada Europejska podejmuje decyzję o nazwie wspólnej } \\
\text { waluty oraz wyznacza plan przyjęcia euro i wymiany pieniądza. }\end{array}$ \\
\hline Grudzień 1996 & EIW przedstawia Radzie Europejskiej wzory banknotów. \\
\hline Czerwiec 1997 & Rada Europejska ustanawia Pakt stabilności i wzrostu \\
\hline Maj 1998 & $\begin{array}{l}\text { Warunki przyjęcia euro jako wspólnej waluty spełniają Belgia, Niemcy, Hiszpania, } \\
\text { Francja, Irlandia, Włochy, Luksemburg, Holandia, Austria, Portugalia i Finlandia. } \\
\text { Powołanie członków Zarządu EBC. }\end{array}$ \\
\hline Czerwiec 1998 & Utworzenie EBC i ESBC. \\
\hline Styczeń 1999 & Rozpoczęcie trzeciego etapu UGiW - euro wspólną walutą strefy euro. \\
\hline Styczeń 2001 & Przystąpienie Grecji do strefy euro. \\
\hline Styczeń-czerwiec 2002 & $\begin{array}{l}\text { Wymiana pieniędzy: banknoty i monety euro wchodzą do obiegu i stają się jedynym } \\
\text { prawnym środkiem płatniczym w strefie euro. }\end{array}$ \\
\hline Styczeń 2007 & Przystapienie Słowenii do strefy euro. \\
\hline Styczeń 2008 & Przystapienie Cypru i Malty do strefy euro. \\
\hline Styczeń 2009 & Przystapienie Słowacji do strefy euro. \\
\hline Grudzień 2009 & Wejście w życie Traktatu z Lizbony. \\
\hline Styczeń 2011 & Przystapienie Estonii do strefy euro. \\
\hline
\end{tabular}

Źródło: Opracowanie własne. 
Należy zauważyć, że Traktat z Lizbony, który wszedł w życie w 2009 r. istotnie znowelizował instytucjonalne i ekonomiczne ramy UGiW. Do najważniejszych zmian instytucjonalnych wprowadzonych postanowieniami traktatu w omawianych sprawach należą:

- włączenie Europejskiego Banku Centralnego do grona podstawowych instytucji UE;

- wprowadzenie podstawy traktatowej dla Eurosystemu i Eurogrupy;

- modyfikacja procedury przejścia ze stanu derogacji do stanu pełnego członkostwa w UGiW;

- wzmocnienie roli Komisji Europejskiej (KE) m.in. w zakresie nadzoru wielostronnego związanego z procedurą nadmiernego deficytu.

\section{Wnioski}

UGiW, w obecnym kształcie, składa się z 17. państw. Stanowi więcej niż cel sam $\mathrm{w}$ sobie jest bowiem realnym stymulatorem integracji gospodarczej i politycznej. Wskazują na to dyskusje nad Traktatem o stabilności, koordynacji i zarządzaniu w unii gospodarczej i walutowej (tzw. pakcie fiskalnym), który został uzgodniony 30 stycznia 2012 roku na nieformalnym posiedzeniu Rady Europejskiej przez 25 państw Unii Europejskiej, z wyjątkiem Wielkiej Brytanii i Czech. Zwolennicy paktu fiskalnego podkreślaja, że w przypadku jego wejścia, do czego wystarczy ratyfikacja przez 12 z 17 państw strefy euro, w sposób istotny wzmocniona zostałaby dyscyplina budżetowa państw członkowskich Unii Europejskiej. Z kolei jego przeciwnicy zwracają uwagę na niebezpieczeństwo dalszego różnicowania poziomu integracji gospodarczej już nie tylko w samej UE, ale także w strefie euro. Duże zaangażowanie Niemiec na drodze do uzyskania mocnego środka dyscyplinującego inne państwa strefy euro sprawia, że w komentarzach politycznych wraca się do rozważań o koncepcji Europy o wielu prędkościach $^{67}$. Jak zauważył Krzysztof Popowicz, wiązana jest ona ze słowami byłego kanclerza Niemiec Willy Brandta. W 1974 roku W. Brandt stwierdził, że Europa potrzebuje polityki stopniowania $\mathrm{w}$ rozwoju integracji, z powodu silnych różnic gospodarczych, zaś mechaniczne utrzymywanie zasady wspólnego kroczenia wszystkich państw członkowskich wpłynąć może na poważne zahamowanie rozwoju wspólnot ${ }^{68}$.

Wiele kontrowersji budzi też udział instytucji Unii Europejskiej w zarządzaniu gospodarczym. W pakcie fiskalnym silną pozycję uzyskują Komisja i Trybunał Sprawie-

${ }^{67}$ J. Ruszkowski, do „ojców” koncepcji „Europy różnych prędkości” zalicza byłego kanclerza Niemiec - Willi Brandta (koncepcja Europy o wielu prędkościach), b. premiera Belgii Leo Tindemansa (dwutorowy rozwój, integracja wielowarstwowa), b. Przewodniczącego Komisji Europejskiej Jacquesa Delorsa (Europa zmiennych geometrii, Europa kręgów koncentrycznych), b. premierów Wielkiej Brytanii J. Thatcher, J. Majora (Europa a la carte), b. wiceprzewodniczącego Komisji Europejskiej ds. polityki zagranicznej i handlowej oraz współpracy z krajami europejskimi Fransa Andriessena (członkostwo afiliowane), polityków niemieckich Karla Lamersa i Wolfganfa Schäuble (model „twardego rdzenia”), b. ministra spraw zagranicznych Niemiec Joschkę Fischera (cetrum grawitacji), b. premiera Francji Alaina Juppe (Europa dwóch kręgów). Por. J. Ruszkowski, Wstęp do studiów europejskich, Warszawa 2007, s. 147-162.

${ }^{68}$ K. Popowicz, Dynamika integracji europejskiej, Warszawa 2004, s. 39. 
dliwości Unii Europejskiej kosztem państw członkowskich i pozostałych instytucji UE. Jurysdykcją Trybunału objęty zostaje obowiązek odpowiedniego wdrożenia do krajowych porządków prawnych reguły budżetowej, ograniczającej poziom strukturalnego deficytu budżetowego do $0,5 \%$ rocznie w stosunku do nominalnego PKB. Instytucji tej przyznaje się także uprawnienie do nakładania kar lub ryczałtu w wysokości $0,1 \%$ PKB na państwa, które nie wykonały jego wyroku wskazującego na naruszenie we wdrożeniu tych przepisów ${ }^{69}$. Równocześnie ostateczna wersja paktu nie satysfakcjonuje Parlamentu Europejskiego. Instytucja ta nie uzyskała w jego ramach większych prerogatyw. Co więcej zgłaszane przez PE propozycje, np. w zakresie wprowadzenia podatku od transakcji finansowych (który w latach 30. XX wieku proponował John M. Keynes, a w latach 70. zasugerował James Tobin), nie zostały uwzględnione, co w Strasburgu uznano za porażkę.

W dobie turbulencji finansowych i gospodarczych w Unii Europejskiej oraz poważnych problemów politycznych grożących wyhamowaniem, a nawet regresem procesu integracji europejskiej, na co wskazuje m.in. dyskusja nad utrzymaniem w obowiązującym kształcie porozumienia z Schengen, rola instytucji bankowo-finansowych, jako jednego z filarów gospodarek narodowych państw członkowskich jest trudna do przecenienia. Sektor bankowy, słusznie jest symboliczne porównywany do „serca” czy też „krwioobiegu” gospodarki. „Sercem” sektora bankowego w UE jest Europejski Bank Centralny. Prawodawca europejski, decydując się na wyniesienie Europejskiego Banku Centralnego do rangi instytucji Unii Europejskiej, zdaje się doceniać wagę problemów ekonomicznych. Rola tej instytucji rośnie dodatkowo w dobie kryzysu finansowego, a Frankfurt nad Menem, będący siedzibą EBC w oczach polityków europejskich staje się jednym z ostatnich bastionów oporu przeciw destabilizacji walutowej, a także „tymczasową stolicą UE”, w której zapadają istotne decyzje, rzutujące na przyszłość państw członkowskich najbardziej zagrożonych recesją lub bankructwem. Paradoksalne jest to, że o przyszłości suwerennych państw decyduje utworzona przez nie instytucja ponadnarodowa, często w przeszłości niedoceniana i stawiana niżej „,w hierarchii” od innych ciał ponadnarodowych - Komisji, Parlamentu Europejskiego czy Trybunału Sprawiedliwości Unii Europejskiej.

Konsekwentne wzmacnianie systemu instytucjonalnego UGiW może jednak budzić zastrzeżenia, odnośnie do legitymizacji i rozliczalności instytucji takich jak EBC, które powiększają pole swojej niezależności. Ta ostatnia cecha jest jednocześnie silnym i słabym punktem Europejskiego Banku Centralnego. Przeciwnicy niemieckiego modelu bankowości, przyjętej za podstawę jego funkcjonowania, podkreślają coraz mniejsze możliwości wpływania państw członkowskich na funkcjonowanie EBC. Wskazują że ta instytucja to najbardziej niezależny bank na świecie koncentrujący się głównie na zapewnianiu stabilności cen, a więc niskiej inflacji. Zauważają, że zmiana mandatu EBC jest w praktyce bardzo trudna do przeprowadzenia (zmiana jego statusu wymaga nowelizacji traktatów). Poza tym istnieje bardzo mało mechanizmów kontrolnych, które gwarantowałby, że polityka tej instytucji będzie zgodna z życzeniami państw członkowskich.

69 A. Gostyńska, P. Tokarski, Spór o nowy pakt fiskalny - analiza i ocena, „Biuletyn”, PISM, nr 17 (882), 14 luty 2012 r., s. 2610-2611. 
Wydaje się, że krytycy systemu instytucjonalnego UGiW mają rację, kiedy wskazują na fakt, że jest on niepełny. Zdaniem Tomasza Grzegorza Grosse ${ }^{70} \mathrm{i}$ innych ekspertów $^{71}$, zasadniczym źródłem problemów jest to, że gospodarki Eurolandu nie spełniają warunków niezbędnych do wprowadzenia wspólnej waluty, zgodnie z założeniami teorii optymalnego obszaru walutowego (ang. optimum currency area). Ponadto w strefie euro wystąiły zjawiska różnicowania warunków ekonomicznych między członkami UGiW, co uwidoczniło się zwłaszcza w poziomie inflacji oraz konkurencyjności gospodarczej lokalnych przedsiębiorstw ${ }^{72}$. Dodajmy też, że stopniowo postępująca integracja walutowa, której motorem jest EBC określający politykę monetarną dla całej strefy euro, kontrastuje ze stosunkowo mało skutecznym realizowaniem przez niego zadań związanych ze wspieraniem polityk gospodarczych w Unii Europejskiej. Polityka finansowa i budżetowa prowadzone są przez rządy poszczególnych państw, co w dobie kryzysu strefy euro nie służy utrzymaniu stabilizacji w UGiW. Z tego też względu nie tylko rząd francuski, ale też czołowi luminarze polityki europejskiej na czele z Angelą Merkel nawołują do utworzenia „europejskiego rządu gospodarczego” (fr. gouvernment économique), którego zaletą może być wprowadzenie równowagi wynikającej z restrykcyjnej polityki pieniężnej. Zdaniem rzecznika tego rozwiązania - J. Buzka - w krótkookresowej perspektywie UE czeka szereg działań doraźnych, takie jak: działania pozwalające przezwyciężyć kryzys w Grecji, Irlandii, Hiszpanii i Portugalii, dokapitalizowanie banków i „stworzenie zapory ogniowej” przeciwko rozprzestrzenianiu się kryzysu. Natomiast w średniookresowej perspektywie UE powinna się skupić na działaniach zmierzających do zapobiegania powtarzaniu się kryzysu. Ich zwieńczeniem mógłby być rząd gospodarczy w UE, pozostający pod kontrolą Parlamentu Europejskiego. Podejmowane przez niego decyzje powinny być wcielane w życie przez Komisję Europejską ${ }^{73}$.

Pomimo wielu głosów popierających ideę rządu gospodarczego w UE należy rozpatrywać ją z rozwagą. Poza oficjalną retoryką ,,wspólnego rynku” poszczególne państwa członkowskie rozgrywają bowiem własną politykę, całkowicie sprzeczną z zasadą lojalnej współpracy leżącej u podstaw Unii Europejskiej. Do takiego wniosku skłaniają m.in. kontrowersje wokół forsowanej jesienią 2011 roku przez Francję koncepcji powiązania polityki budżetowej między państwami „17” poprzez tworzenie rządu ekonomicznego ograniczonego jedynie do tzw. Eurogrupy. Państwo to starało się ,przy okazji” zwiększyć konkurencyjność gospodarki francuskiej w UE poprzez ujednolicenie podatku od przedsiębiorstw we Francji i w Niemczech zaplanowane na 2013 rok. Można przyjąć, że takie rozwiązanie wpłynęłoby na zmniejszenie konkurencyjności

70 T. G. Grosse, Kryzys europejskiej waluty. Konsekwencje polityczne, „Analizy natolińskie” 2011, nr 3(51), s. 6.

71 J. Pisani-Ferry, Only One Bed for Two Dreams: A Critical Retrospective on the Debate over the Economic Governance of the Euro Area, ,Journal of Common Market Studies”2006, Vol. 44, Issue 4, s. 823-844; Ch. Wyplosz, European Monetary Union: the dark sides of a major success, „Economic Policy” 2006, Vol. 26 (46), s. 207-261.

${ }_{72}$ T. G. Grosse, ibidem.

73 Buzek, Trzeba stworzyć europejski rzqd gospodarczy, http://www.pap.com.pl/palio/html.run?_Instance $=$ cms_ep.pap.pl\&_PageID $=1 \&$ _menuId $=17 \&$ nrDep $=29058 \&$ CheckSum $=$ 1420160134, odczyt z dn. 12.03 .2012 r. 
inwestycyjnej w nowych państwach UE. W interesie strony polskiej i innych średnich i małych państw członkowskich UE, zwłaszcza tych, które pozostają poza strefą Euro, jest niedopuszczenie do ziszczenia się wizji trwałego podziału na „Europę dwóch prędkości”. Doprowadzenie do stworzenia europejskiego rządu gospodarczego, a nawet unii bankowej zmierzającej do zwiększenia nadzoru i regulacji europejskich nad sektorem bankowym ${ }^{74}$ jest, ze względu na priorytet utrzymania wysokiego tempa wzrostu gospodarczego w Polsce, bardzo dyskusyjne. Wykorzystanie przez europejski rząd gospodarczy instrumentów w celu pobudzenia wzrostu gospodarczego w „starych” państwach UE może sprawić, że nastapi zmiana kierunków strumieni finansowania w zakresie np. polityki regionalnej, czego skutkiem może być zawężenie szans na faktyczne wyrównywanie poziomu życia pomiędzy europejskimi peryferiami, a obszarami rozwiniętymi gospodarczo. Zamiast tego znaczne środki mogą być kierowane z powrotem do najbardziej rozwiniętych państw europejskich pod pozorem walki z bezrobociem, inwestycji w infrastrukturę itp. W związku z powyższym do idei rządu gospodarczego w Europie należy podchodzić ostrożnie pamiętając, że o ile EBC jest w swoich decyzjach instytucją niezależną ${ }^{75}$, o tyle na jakikolwiek gabinet polityczny w Europie zawsze wpływ będą miały państwa najsilniejsze.

\section{Summary}

\section{Economic and Monetary Union: the origins, evolution and development prospects}

This paper touches upon the origin, evolution and development prospects of Economic and Monetary Union (EMU). Its theoretical foundations are considered, as well as the historical, institutional and normative aspects of monetary and economic integration within the European Union. Considerable attention is paid to EU institutions' participation in economic management, in particular to the European Central Bank, which is the pivot of monetary and economic stabilization in the European Union. The paper also emphasizes the potential changes applying to EMU following the Lisbon Treaty that may be introduced after signing the Treaty on Stability, Coordination and Governance in the Economic and Monetary Union (Fiscal Treaty) and establishing an economic government.

74 Por. T. G. Grosse, Doświadczenia regulacji sektora bankowego w Unii Europejskiej wobec planów wprowadzenia unii bankowej, Analiza Instytutu Sobieskiego, wrzesień 2012, nr 47, s. 2.

75 Trzeba jednak zauważyć, że niezależność EBC jest czysto formalna. W praktyce zasada ta była wielokrotnie łamana zwłaszcza w okresie kryzysu strefy euro. Ostatnim przykładem jest uzależnienie działań EBC (skup obligacji rządów na rynku wtórnym) od decyzji polityków narodowych decydujących o warunkach pomocy Europejskiego Mechanizmu Stabilizacyjnego. 